\title{
Farm Biosecurity at backyard poultry of Bangladesh and its role in spread of HPAl
}

\author{
Muhammad Asaduzzaman* \\ International Centre for Diarrheal Disease Research, Bangladesh, Dhaka, Bangladesh
}

\section{Objective}

We have conducted this study to characterise the movement and contact patterns of poultry in Bangladesh that could be associated with transmission of newly-introduced subtypes of avian influenza virus in two districts of Bangladesh as well as to summarise the patterns arising from the network analysis in a way that can inform the parameterisation of spatially explicit stochastic models of transmission of newly-introduced subtypes of avian influenza virus in the two types of areas.

\section{Introduction}

Bangladesh is a South Asian country with large human and poultry populations which is highly affected with frequent outbreaks of both high and low pathogenic avian influenza since 2007. Very few studies have been carried out to reveal the farm biosecurity at backyard poultry that might have contributed to the spread of avian influenza in Bangladesh, specially rural areas. Therefore, we aimed to characterize biosecurity practices of poultry farm including the movement of live birds which is a well-known risk factor for the geographic dissemination of the virus among poultry flocks and personnel hygiene of poultry workers for rapid detection and effective risk management of incursion of HPAI and LPAI viruses.

\section{Methods}

This cross sectional survey was carried out using a pretested questionnaire in backyard Poultry holdings of Kalkini Upazila of Madaripur district in Dhaka division which has a relatively low proportion of commercial poultry farms and high proportion of backyard poultry holdings. 1-mode and 2-mode social network analysis was also carried out to show the farm to farm movements. From each primarily selected farm, details of the last 2 movements of live poultry along with source/destination details was collected with pre-tested questionnaire. Later, data was stored in Epi-Info, analysed with STATA 14 and UCINET. 315 backyard HH from 2 villages of Kalkini Upazila, Madaripur District were randomly selected.

\section{Results}

The study revealed that majority backyard farm owners do not maintain the standard biosecurity measures whereas a significant amount of the study included farms rear multiple poultry species. No poultry workers were found to use any personal protective equipment (PPEs) while cleaning the litter/mats (Figure 2). The farms with multiple poultry species feed them in same container and keep them in same shed which is a major risk factor for disease transmission. Movement patterns differed in a number of aspects (Table 1) and this information is useful for the establishment of the movement parameter settings in a simulation model of avian influenza incursion.

\section{Conclusions}

The findings on farm biosecurity practices and movement pattern from this study will support to develop risk-based surveillance and contingency policies as well as to minimize the spread between poultry units and also from poultry to people for novel AI viruses in Bangladesh.

Farm to Farm Movement of Live Birds (1-Mode Network Analysis)

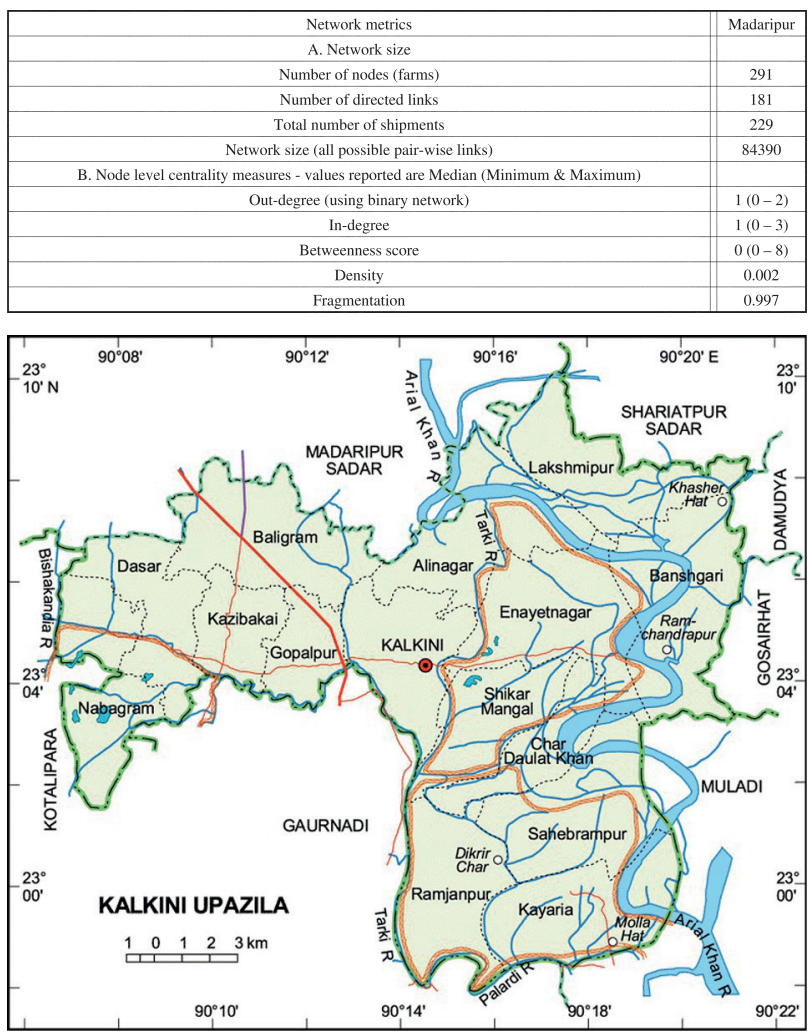

Figure 1. Study Area 


\section{ISDS 2018 Conference Abstracts}

\begin{tabular}{|c|c|c|c|}
\hline \multirow[t]{2}{*}{ Farm characteristics } & \multirow[t]{2}{*}{ Categories } & \multicolumn{2}{|c|}{ Madaripur (n= 315) } \\
\hline & & Freq & $\%$ \\
\hline \multirow{2}{*}{$\begin{array}{l}\text { Keep ducks in the same night shelter } \\
\text { with the poultry }\end{array}$} & Yes & 25 & 7.94 \\
\hline & No & 290 & 92.06 \\
\hline \multirow[t]{3}{*}{ Bring back unsold poultry } & Yes & 0 & 0.00 \\
\hline & No & 190 & 60.32 \\
\hline & $\begin{array}{l}\text { Do not sell any } \\
\text { poultry }\end{array}$ & 125 & 39.68 \\
\hline \multirow[t]{4}{*}{$\begin{array}{l}\text { keep of bring back poultry upon } \\
\text { unsold at market }\end{array}$} & $\begin{array}{l}\text { Isolated from the } \\
\text { flock }\end{array}$ & 0 & 0.00 \\
\hline & Mix with the flock & 0 & 0.00 \\
\hline & $\begin{array}{l}\text { Do not bring back } \\
\text { unsold poultry }\end{array}$ & 190 & 60.32 \\
\hline & Do not sell any poultry & 125 & 39.68 \\
\hline \multirow[t]{4}{*}{ Place of poultry slaughter } & $\begin{array}{l}\text { Outside the home } \\
\text { yard }\end{array}$ & 136 & 43.17 \\
\hline & $\begin{array}{l}\text { Inside the yard but } \\
\text { separate from the } \\
\text { house }\end{array}$ & 176 & 55.87 \\
\hline & $\begin{array}{l}\text { Place attached to the } \\
\text { house }\end{array}$ & 3 & 0.95 \\
\hline & Inside the house & 0 & 0.00 \\
\hline \multirow[t]{7}{*}{ Disposal of offal's } & Bury & 16 & 5.08 \\
\hline & Through & 139 & 44.13 \\
\hline & Fish & 87 & 27.62 \\
\hline & All above & 1 & 0.32 \\
\hline & $\begin{array}{l}\text { Bury and Through in } \\
\text { open place }\end{array}$ & 2 & 0.63 \\
\hline & $\begin{array}{l}\text { Bury and Feed to fish/ } \\
\text { animals }\end{array}$ & 0 & 0.00 \\
\hline & Through and Feed & 70 & 22.22 \\
\hline \multirow[t]{2}{*}{ Allow birds to roam inside house } & Yes & 301 & 95.56 \\
\hline & No & 14 & 4.44 \\
\hline \multirow{2}{*}{$\begin{array}{l}\text { Separate sick birds from the healthy } \\
\text { bird }\end{array}$} & Yes & 78 & 24.76 \\
\hline & No & 237 & 75.24 \\
\hline \multirow[t]{4}{*}{ Keep the sick birds } & $\begin{array}{l}\text { In the living room } \\
\text { where household } \\
\text { member sleep at } \\
\text { night }\end{array}$ & 58 & 18.41 \\
\hline & $\begin{array}{l}\text { Inside poultry shed } \\
\text { where healthy birds } \\
\text { are kept at night }\end{array}$ & 219 & 69.52 \\
\hline & $\begin{array}{l}\text { Outside of the poultry } \\
\text { shed but attached }\end{array}$ & 38 & 12.06 \\
\hline & Other & 0 & 0.00 \\
\hline
\end{tabular}

Figure 2. Biosecurity Practices in Backyard Farms of Madaripur District

\section{Keywords}

Farm Biosecurity; HPAI; Backyard Poultry

\section{Acknowledgments}

We thank European Commission for funding and implementation of this work.

*Muhammad Asaduzzaman

E-mail: asaduzzaman@icddrb.org 